\title{
Puzzling Results from BAP1 Germline Mutations Analysis in a Group of Asbestos-Exposed Patients in a High-risk Area of Northeast Italy
}

\author{
CLARA RIZZARDI ${ }^{1}$, EMMANOUIL ATHANASAKIS ${ }^{2}$, FRANCESCA CAMMISULI $^{1}$, SIMEONE DAL MONEGO $^{3}$, \\ YERALDIN CHIQUINQUIRA CASTILLO DE SPELORZI ${ }^{4}$, FULVIO COSTANTINIDES ${ }^{1}$, FABIOLA GIUDICI ${ }^{1}$, \\ MAURIZIO PINAMONTI ${ }^{1}$, VINCENZO CANZONIERI ${ }^{5}$, MAURO MELATO $^{6}$ and LORELLA PASCOLO ${ }^{1}$ \\ Departments of ${ }^{1}$ Medical, Surgical and Health Sciences, ${ }^{4}$ Life Sciences, and \\ ${ }^{6}$ Pathology and Forensic Medicine, University of Trieste, Trieste, Italy; \\ ${ }^{2}$ Institute for Maternal and Child Health, IRCCS Burlo Garofolo, Trieste, Italy; \\ ${ }^{3}$ Cluster in Biomedicine, CBM S.c.r.l., Bioinformatic Services, Area Science Park, Trieste, Italy; \\ ${ }^{5}$ Oncology Referral Center, National Cancer Institute, Aviano, Italy
}

\begin{abstract}
Background: Germline mutations of the oncosuppressor gene breast cancer 1-associated protein 1 (BAP1) were recently related to an autosomal-dominant tumor predisposition syndrome (BAP1-TPDS), characterized by uveal melanoma, malignant mesothelioma (MM), cutaneous melanoma, and other malignancies. The demonstration that BAP1 mutations are strongly associated with MM has provided a real breakthrough in the study of genetic predisposition in $M M$, that may explain why only a fraction of asbestos-exposed individuals go on to develop MM. Materials and Methods: To evaluate the possible role of BAPI mutations in the epidemiology of sporadic MM, and their relationship with asbestos exposure, we determined the prevalence of germline BAP1 mutations by the Sanger method in a group of 29 asbestos-exposed patients, 21 of which were diagnosed with MM. They were residents of Trieste, a ship-building town in Northeast Italy with a very high incidence of mesothelioma. Results: We identified non-obviously pathogenetic germline sequence variants of BAPl in 3/29 patients and in 2/21 MM cases (10\%). Conclusion: Non obviously pathogenic germline sequence variants of BAP1 were found. Nevertheless, limitations of predictive web tools allowed us to comment on some interesting peculiarities of our findings.
\end{abstract}

This article is freely accessible online.

Correspondence to: Clara Rizzardi, MD, Unit of Pathology, Department of Medical, Surgical and Health Sciences, University of Trieste, c/o Ospedale di Cattinara, Strada di Fiume 447, 34149 Trieste, Italy. Tel: +39 0403996239, Fax: +39 0403996247, e-mail: crizzardi@units.it

Key Words: BAP1, germline mutations, mesothelioma, asbestos.
Malignant mesothelioma (MM) is a highly aggressive malignancy that arises from mesothelial cells of serosal surfaces, primarily the pleura and peritoneum, and less often the pericardium or tunica vaginalis, with a median survival of 1 year from diagnosis (1). The single most important risk factor for MM is exposure to asbestos (2-4). Nevertheless, the observation that only a fraction $(10-17 \%)$ of asbestosexposed individuals actually go on to develop MM (5) and the identification of clusters of MM cases within certain families suggest that genetics influence carcinogenesis from mineral fibers (6-9). The demonstration that mutations in the tumor-suppressor gene breast cancer 1 -associated protein 1 $(B A P 1)$ are strongly associated with MM has provided a real breakthrough in the study of genetic predisposition to MM (8). In families with BAP1 mutation, there is a dramatically increased incidence of malignant tumors overall, often developed at an earlier age than observed in the general population. Recently, germline mutations of $B A P 1$ have been related to a hereditary tumor predisposition syndrome characterized by uveal melanoma, MM, cutaneous melanoma, and possibly several other malignancies (8-12).

The molecular functions of BAP1, as well as the penetrance and the phenotypic spectrum of germline mutations of the gene, however, have still to be clarified, as does the role of gene-lifestyle/environmental interactions in the development of these tumors. To give our contribution in shedding light on the possible role of $B A P 1$ mutations in the epidemiology of sporadic MM, and their relationship with asbestos exposure, we determined the prevalence of germline $B A P l$ mutations in an unselected sample of 29 asbestos-exposed patients, 21 of which were diagnosed with MM. The patients were residents of Trieste, a ship-building town of about 200,000 inhabitants in Northeast Italy that may be considered as hyperendemic for 
mesothelioma. The standardized incidence rate (European population) due to mesothelioma among male residents in the provinces of Trieste and Gorizia was $13.2(13,14)$ compared to national rates ranging from 3.2 and 2.0 per 100,000 persons per year (15).

\section{Materials and Methods}

Tissue samples. Tissues samples were obtained from 29 autopsy cases randomly selected from the archives of the Institute of Forensic Medicine of the University of Trieste. All the cases were subjected to legal medical advice to establish the cause of death and a possible correlation to professional exposure to asbestos and to the presence of asbestos-related diseases. Clinical features were extracted including sex, age at death, asbestos exposure, cause of death and concurrent diseases including malignancies, and in patients with MM, age at diagnosis, histology, stage, and treatment including surgery, chemotherapy, and radiation, as well as the duration of survival.

MM cases were histologically diagnosed either during their clinical course or at post-mortem examination, according to the standard histological and immunohistochemical criteria, and classified according to the WHO classification of pleural tumors (16). Diagnosis of asbestosis was made according to the criteria reported by the Asbestosis Committee of the College of American Pathologists and Pulmonary Pathology Society (17).

The quantification of asbestos bodies in the lung parenchyma was performed in accordance with the method of Smith and Naylor with slight modifications (18).

Nucleic acid extraction and polymerase chain reaction (PCR) amplification. Genomic DNA of 29 patients was extracted from frozen tissues using QIAamp DNA Mini Kit (Qiagen, Hilden, Germany) according to the manufacture's protocol. PCR amplification of 17 BAPl exons and of all their exon-intron boundaries (NCBI accession number: NM_004656.3) was performed as previously described by Bortot et al. (19). Briefly, primer design was performed using Primer3web v4.0.0 on-line software $(20,21)$ (Table I). All amplifications were carried out using KAPA2G Fast ReadyMix (Kapa Biosystems, Cape Town, South Africa) in a 96-well PCR plate and sharing a common annealing temperature in a two-cycle step touchdown protocol: primary, an initial denaturation step at $96^{\circ} \mathrm{C}$ for 3 minutes was followed by a touchdown step planning to decrease the temperature by $0.5^{\circ} \mathrm{C} /$ cycle, through 10 cycles: $95^{\circ} \mathrm{C}$ for 15 seconds, $62^{\circ} \mathrm{C}$ for $15 \mathrm{sec}$, and $72^{\circ} \mathrm{C}$ for 1 second; secondary, an endpoint-PCR step through 30 cycles was performed: $95^{\circ} \mathrm{C}$ for $10 \mathrm{sec}, 59^{\circ} \mathrm{C}$ for $10 \mathrm{sec}$, and $72^{\circ} \mathrm{C}$ for 1 second.

Total RNA was isolated from frozen tissues using EuroGOLD Total RNA Kit (EuroClone, Milan, Italy). Reverse transcription (RT) reaction was performed using the GoScript Reverse Transcription System (Promega, Madison, WI, USA) according to the manufacture's protocol. Briefly, RT was performed in a reaction volume of $5 \mu \mathrm{l}$ containing $5 \mu \mathrm{g}$ of total RNA and $15 \mathrm{pM}$ of each sequence-specific primer (Table I). Primers were designed using the on-line NCBI Primer-BLAST tool (22) and their specificity was checked on the RefSeq mRNA database. Finally, cDNA PCR amplification was performed according to the above described touchdown protocol using the same sequence-specific primers of each RT reaction.
Sanger sequencing and mutation data handling. PCR products were purified using Illustra ExoStar 1-Step kit (GE Healthcare, Little Chalfont, UK) according to the manufacturer's protocol. Sequencing of the PCR fragments was carried out using BigDye Terminator v3.1 Cycle Sequencing kit (Life Technologies, Foster City, CA, USA) following the manufacturer's instructions. Automated electrophoresis was performed on an ABI 3500Dx Genetic Analyzer and the sequencing results were analyzed using SeqScape v2.7 software (Life Technologies).

All identified variants were annotated using a custom bioinformatics pipeline basic on Annovar software (23) and referring to several databases as reported in Table II. To detect alterations in exon-intron boundary regions and splicing motifs due to nucleotide changes, the bioinformatics tools for splice site prediction HSF (24), NNSplice (25), NetGene (26) and SPANR (27) were used. All selected variants were reconfirmed either on genomic DNA or, in case of splicing site mutations, on cDNA by Sanger sequencing.

An in silico mutation analysis was performed for the nonsynonymous selected mutation to predict if the amino acid substitution involves a structural modification of BAP1 protein. A web-based resource for template-based modeling, Phyre2 v2.0 (28), was used. Wild-type amino acid sequence (NCBI accession number: NP_004647.1) was submitted through the intensive method in order to obtain a pdb structure. The outcome wild-type protein structure present a structural homology at $100 \%$ of confidence with the ubiquitin carboxyl-terminal hydrolase isozyme 15 (PDB ID: 3IHR) from amino acids 5 to 238 of the query sequence. The modeling of the remaining amino acid sequence was predicted. As a second attempt, the mutated amino acid sequence was aligned using the same tool on the wild-type protein obtained previously. Analyses of all docked poses were performed using the molecular visualization software UCSFChimera v1.10.2 (29).

Multiplex ligation-dependent probe amplification (MLPA). The $B A P 1$ gene was analyzed by MLPA (30) using the SALSA MLPA P471-BAP1 - LOT1011 (B1) probe mix (MRC Holland, Amsterdam, the Netherlands). MLPA reactions were performed, using $75 \mathrm{ng}$ of genomic DNA according to the manufacturer's instructions. The products were separated by capillary electrophoresis on an ABI 3130XL Genetic Analyzer and controlled using the Gene Mapper v4.0 software (Life Technologies). Copy number variations were predicted for each patient using the Coffalyzer.Net v140721 software (MRC Holland).

\section{Results}

Of 29 patients, there were 26 men (90\%) and three women $(10 \%)$. At the time of death, the patients' ages ranged from 58 to 91 years $($ mean \pm SD: $76 \pm 9$ years). They included 21 cases of MM (20 pleural and one peritoneal), two cases of squamous cell carcinoma and one of adenocarcinoma of the lung, and one case of squamous cell carcinoma of the oral cavity metastasized to the lungs. Four patients had nonneoplastic diseases including two cases of asbestosis, one of pulmonary fibrosis, who had also an incidental renal cell carcinoma, and one had pleural plaques only. 
Table I. List of all primers used for Sanger sequencing of DNA and cDNA target regions.

\begin{tabular}{|c|c|c|}
\hline Exon number & Forward 5' to 3 ' & Reverse 5' to 3' \\
\hline \multicolumn{3}{|l|}{ BAP1, NG_031859.1 } \\
\hline 1 & gttcgecttcgagcgcatg & cacgagcagggtgaagaggc \\
\hline 2 and 3 & gaataagggctggctggagctg & gccetgttctctgggaccttc \\
\hline 4 & cacagcaaggacacctgagtgatg & cttcctccatttccacttcccaagc \\
\hline 5 & gttgtccagatatgactgacctgctc & catgtggtagcattcccagtgg \\
\hline 6 and 7 & cgtctgtgttccttccgattcetg & gctggtcgggcaatatggtgtag \\
\hline 8 & ctacaccatattgecegaccagc & cccatgatctaagcetgatcttgcc \\
\hline 9 & tgccaggatatctgectcaacct & gctgaagcccagatctacaagagagt \\
\hline 10 & gaatgggtagagccaaggcc & agactttccetgtttaggectcce \\
\hline 11 & gcttgctgactcccattgcac & accacatgggaaaattgcctgttg \\
\hline 12 & gactcagtctggaaaaccatgttggc & aggtgctcaacattatctgctgca \\
\hline 13 & gtcgggatgtatttaagccattctgggt & tgcaggacactttgtggtcacttg \\
\hline 14 & gtgatctgggtcctgtcatcagc & aggcaaggatgagcagcgagtc \\
\hline 15 and 16 & ctcgetgctcatcettgect & caaggtctgctcaagcctcagga \\
\hline 17 & tcctgaggettgagcagacettg & agggcacgatggaaggaatgtg \\
\hline Exons and cDNA start-end position & Forward 5' to 3' & Reverse 5' to 3' \\
\hline \multicolumn{3}{|l|}{ BAP1 NM_004656.3,CCDS2853.1 } \\
\hline Exons 9-11, $715-941$ & atcaagtatgaggccaggctg & tctgcaccatctgtgtggttg \\
\hline Exons $10-12,921-1127$ & cgctggtgctggaagcaaac & tcttcttcetcctgcatggg \\
\hline Exons $13-14,1628-1845$ & agcetgctgcgtgttgactg & catccecgtettctctctgetgtc \\
\hline
\end{tabular}

Of the 21 patients with MM, 18 were men (86\%) and three were women $(14 \%)$. At the time of death, the patients' ages ranged from 58 to 88 years (mean \pm SD: $76 \pm 9$ ). MM was the cause of death in 18 cases, while in three cases, death was attributable to other causes. In some of the 21 patients with MM, other malignancies were documented such as prostatic carcinoma, oral squamous cell carcinoma, bladder carcinoma and squamous cell carcinoma of the contralateral lung. Of the 20 cases of pleural MM, 15 were epithelioid, and four biphasic. In one case, the histotype of MM was not available. The case of peritoneal MM was of the epithelioid type. A summary of clinical features is reported in Table III.

Among these 29 patients with a history of asbestos exposure, Sanger sequencing of BAPl gene identified one non-synonymous variant and two intronic variants. MLPA analysis did not reveal significant copy number variations at the exon level in any of patient samples.

In detail, patient 4 heterozygously carried a known intronic variation 8 bases downstream of exon 13 (c.1729+8T>C) (Figure 1). This variant has already been described as a single-nucleotide pleomorphism (rs150945583) with a minor allelic frequency of between 0.0030 and $0.0055(31,32)$. Web tools for prediction of alternative splicing reported this as a possible alteration of an intronic splicing site. Sanger sequencing of cDNA did not detect alternative splicing forms. This patient was affected by pulmonary fibrosis, and died from respiratory failure. The
Table II. List of all tools and databases used in the present study for the annotation of all identified variants.

RefSeq database version 69

ExAC 65000 exome version 0.3

NIH-NHLBI 6500 exome database version 2

1000 Genomes Project 2014 Oct version

NCBI dbSNP build 142

NCBI ClinVar version 20150330

HGMD professional version 2014.4

COSMIC version 70

CADD, SIFT, Polyphen2, LRT, MutationTaster, MutationAssessor, FATHMM, VEST3, MetaSVM and MetaLR from dbNSFP version 2.6 PhyloP, phastCons, GERP++ and SiPhy from dbNSFP version 2.6 Mutalyzer version 2.0.10

quantification of asbestos bodies in the lung parenchyma revealed the presence of 104 asbestos bodies per gram of dry lung tissue. At autopsy, a clear cell renal cell carcinoma of $40 \mathrm{~mm}$ in the greatest diameter was evidenced as an incidental finding.

Patient 9 heterozygously carried a missense variant (c.T1028C; p.L343P) at exon 11 (Figure 2A). Web tools for prediction of mutation pathogenicity reported this variant as being possibly benign. Sanger sequencing of cDNA revealed no alternative splicing due to the nucleotide change. In silico 
Table III. Summary of clinical features of the 29 patients of the study sample. Patients harboring of breast cancer 1 (BRCA1)-associated protein 1 (BAP1) gene genetic variants are shown in bold.

\begin{tabular}{|c|c|c|c|c|c|c|c|c|c|c|c|}
\hline $\begin{array}{l}\text { Patient } \\
\text { no. }\end{array}$ & Gender & $\begin{array}{l}\text { Age at } \\
\text { diagnosis } \\
\text { (years) }\end{array}$ & $\begin{array}{l}\text { Age at } \\
\text { death } \\
\text { (years) }\end{array}$ & $\begin{array}{c}\text { MM } \\
\text { survival } \\
\text { (months) }\end{array}$ & Cancer & $\begin{array}{c}\text { MM } \\
\text { histotype }\end{array}$ & $\begin{array}{l}\text { Other } \\
\text { diseases }\end{array}$ & $\begin{array}{c}\text { Treatment } \\
\text { of MM }\end{array}$ & $\begin{array}{l}\text { Asbestos } \\
\text { exposure }\end{array}$ & Occupation A & $\begin{array}{c}\text { Asbestos } \\
\text { bodies } \\
(\mathrm{n} / \mathrm{g})\end{array}$ \\
\hline 1 & M & 77.9 & 77.9 & 0.5 & $\begin{array}{l}\text { Pleural mesothelioma; } \\
\text { prostatic carcinoma }\end{array}$ & Epithelioid & I & Palliative & Occupational & Dockworker & 13 \\
\hline 2 & M & 87.3 & 87.6 & 2.6 & Pleural mesothelioma & Epithelioid & l & Palliative & Occupational & Ship mechanic & c 34300 \\
\hline 3 & M & & 72.2 & & $\begin{array}{l}\text { Laryngeal carcinoma; } \\
\text { prostatic carcinoma; } \\
\text { lung carcinoma; } \\
\text { oral carcinoma with } \\
\text { lung metastases }\end{array}$ & 1 & l & 1 & Occupational & Sailor & 8400 \\
\hline 4 & $\mathbf{M}$ & & 70.5 & & Renal cell carcinoma & I & $\begin{array}{l}\text { Pulmonary } \\
\text { fibrosis }\end{array}$ & I & $\begin{array}{r}\text { Occupational } \\
\text { f }\end{array}$ & $\begin{array}{c}\text { Chemical } \\
\text { factory worker }\end{array}$ & 104 \\
\hline 5 & $\mathrm{~F}$ & 84.9 & 85.0 & 0.5 & Pleural mesothelioma & Biphasic & 1 & Palliative & NA & $\mathrm{NA}$ & 94 \\
\hline 6 & M & 71.5 & 72.9 & 16.8 & $\begin{array}{l}\text { Pleural mesothelioma } \\
\text { (circumscribed } \\
\text { non evolutive); } \\
\text { oral carcinoma }\end{array}$ & Epithelioid & I & None & Occupational & Dockworker & 5100 \\
\hline 7 & M & 82.1 & 82.6 & 5.23 & Pleural mesothelioma & Epithelioid & l & Palliative & Occupational & $\begin{array}{c}\text { Engine } \\
\text { factory worker }\end{array}$ & 20000 \\
\hline 8 & M & 57.9 & 68.7 & 126.6 & $\begin{array}{l}\text { Pleural mesothelioma } \\
\text { (healed); bladder } \\
\text { carcinoma; } \\
\text { contralateral } \\
\text { lung carcinoma }\end{array}$ & NA & l & Pneumectomy & NA & $\begin{array}{l}\text { Italian finance } \\
\text { police }\end{array}$ & 55 \\
\hline 9 & $\mathbf{M}$ & 68.3 & 71.8 & 41.1 & Pleural mesothelioma & Epithelioid & $\begin{array}{l}\text { Diffuse } \\
\text { pleural } \\
\text { fibrosis; } \\
\text { desmoid- } \\
\text { type } \\
\text { fibromatosis }\end{array}$ & $\begin{array}{l}\text { Pleurectomy } \\
\text { and } \\
\text { decortication, } \\
\text { multiple } \\
\text { pulmonary } \\
\text { is resections; } \\
\text { chemo- and } \\
\text { radiotherapy }\end{array}$ & Occupational & $\begin{array}{l}\text { Ship engine } \\
\text { room worker, } \\
\text { shipyard } \\
\text { worker }\end{array}$ & 229 \\
\hline 10 & $\mathrm{~F}$ & 68.4 & 69.9 & 17.6 & Pleural mesothelioma & Epithelioid & l & $\begin{array}{l}\text { Pleuropneu- } \\
\text { mectomy; } \\
\text { chemo- and } \\
\text { radiotherapy }\end{array}$ & Household & Housewife & 121 \\
\hline 11 & M & 81.5 & 81.5 & 0.6 & Pleural mesothelioma & Biphasic & 1 & Palliative & NA & $\begin{array}{c}\text { Steel } \\
\text { mill worker }\end{array}$ & 231 \\
\hline 12 & M & 82.1 & 83.6 & 17.5 & Pleural mesothelioma & Epithelioid & I & $\begin{array}{l}\text { Chemo- and } \\
\text { radiotherapy }\end{array}$ & NA & Electrician & 513 \\
\hline 13 & M & & 78.6 & & l & / & Asbestosis & I & Occupational & Dockworker & 5025 \\
\hline 14 & M & & 77.1 & & l & I & Asbestosis & I & Occupational & Ship cook & 6580 \\
\hline 15 & $\mathbf{M}$ & 62.6 & 64.1 & 18.1 & Pleural mesothelioma & Epithelioid & I & Chemotherapy? & ?Occupational & Welder & 31330 \\
\hline 16 & M & 66.5 & 69.4 & 34.2 & Pleural mesothelioma & Epithelioid & l & Pleurectomy & Occupational & Dockworker & 19840 \\
\hline 17 & M & & 69.9 & & l & I & l & I & Occupational & $\begin{array}{c}\text { Engine } \\
\text { factory worker }\end{array}$ & 6690 \\
\hline 18 & M & 57.3 & 60.1 & 32.9 & Peritoneal mesothelioma & Epithelioid & l & $\begin{array}{c}\text { Intestinal } \\
\text { resection; } \\
\text { chemotherapy }\end{array}$ & NA & NA & 25 \\
\hline 19 & M & 82.7 & 82.9 & 2.1 & Pleural mesothelioma & Epithelioid & I & Chemotherapy & Occupational & $\begin{array}{l}\text { Shipyard } \\
\text { worker }\end{array}$ & 119 \\
\hline 20 & M & 64.3 & 65.5 & 14.5 & Lung carcinoma & I & l & I & Occupational & $\begin{array}{l}\text { Glass factory } \\
\text { worker }\end{array}$ & 136 \\
\hline 21 & M & 64.4 & 70.5 & 72.1 & Pleural mesothelioma & Epithelioid & I & $\begin{array}{l}\text { Pleurectomy } \\
\text { and } \\
\text { decortication; } \\
\text { chemotherapy }\end{array}$ & Occupational & $\begin{array}{l}\text { Elevator } \\
\text { technician }\end{array}$ & 485 \\
\hline 22 & M & 74.3 & 74.4 & 1.4 & Pleural mesothelioma & NA & I & Palliative & NA & NA & 75 \\
\hline
\end{tabular}


Table III. Continued

\begin{tabular}{|c|c|c|c|c|c|c|c|c|c|c|c|}
\hline $\begin{array}{l}\text { Patient } \\
\text { no. }\end{array}$ & Gender & $\begin{array}{c}\text { Age at } \\
\text { diagnosis } \\
\text { (years) }\end{array}$ & $\begin{array}{l}\text { Age at } \\
\text { death } \\
\text { (years) }\end{array}$ & $\begin{array}{c}\text { MM } \\
\text { survival } \\
\text { (months) }\end{array}$ & Cancer & $\begin{array}{c}\text { MM } \\
\text { histotype }\end{array}$ & $\begin{array}{c}\text { Other } \\
\text { diseases }\end{array}$ & $\begin{array}{c}\text { Treatment } \\
\text { of MM }\end{array}$ & $\begin{array}{l}\text { Asbestos } \\
\text { exposure }\end{array}$ & Occupation & $\begin{array}{c}\text { Asbestos } \\
\text { bodies } \\
(\mathrm{n} / \mathrm{g})\end{array}$ \\
\hline 23 & M & 55.5 & 58.0 & 29.4 & Pleural mesothelioma & Epithelioid & l & $\begin{array}{l}\text { Pleurectomy } \\
\text { and } \\
\text { decortication; } \\
\text { chemotherapy }\end{array}$ & Occupational & $\begin{array}{c}\text { Occupational } \\
\text { health and } \\
\text { safety } \\
\text { technician }\end{array}$ & 18 \\
\hline 24 & $\mathrm{M}$ & 86.8 & 87.0 & 3.0 & Pleural mesothelioma & Epithelioid & 1 & Palliative & Occupational & Navy officer & 1660 \\
\hline 25 & M & 86.8 & 87.3 & 5.7 & Pleural mesothelioma & Biphasic & I & Palliative & Occupational & Sailor & 1320 \\
\hline 26 & M & 65.1 & 65.8 & 8.2 & Lung adenocarcinoma & I & I & I & Occupational & Dockworker & 11150 \\
\hline 27 & M & 85.7 & 88.4 & 31.1 & Pleural mesothelioma & Biphasic & l & None & NA & NA & 1270 \\
\hline 28 & $\mathrm{~F}$ & 78.9 & 79.9 & 12.3 & $\begin{array}{l}\text { Pleural mesothelioma } \\
\text { (regressed) }\end{array}$ & Epithelioid & l & $\begin{array}{l}\text { Chemo- and } \\
\text { radiotherapy }\end{array}$ & NA & Teacher & 0 \\
\hline 29 & M & & 91.1 & & $\begin{array}{l}\text { Lung carcinoma; } \\
\text { colorectal carcinoma }\end{array}$ & l & Asbestosis & l & NA & Fisherman & 1670 \\
\hline
\end{tabular}

M, Male; F, female; MM, malignant mesothelioma; NA, not available.

mutation analysis was performed for a predicted protein structure of BAP1 protein without any significant possible effect of the amino acid change (Figure 2B). This was a case of pleural epithelioid MM, in a patient with a history of heavy occupational exposure to asbestos, in association with diffuse pleural fibrosis associated with areas of desmoid-type fibromatosis. The patient underwent a multimodality therapy, and died 41 months after diagnosis from advanced-stage MM with pulmonary, pericardial, mediastinal, diaphragmatic, peritoneal and osseous metastases. The quantification of asbestos bodies in the lung parenchyma revealed the presence of 229 asbestos bodies per gram of dry lung tissue.

Finally, for patient 15 , a heterozygous intronic variation 8 bases upstream of the exon 10 (c.784-8G>A) (Figure 3) was identified. Alternative splicing prediction web tools gave contradictory results. Sanger sequencing of cDNA did not detect alternative splicing forms. This was a case of pleural epithelioid MM in a patient with a history of occupational exposure to asbestos. He underwent an unspecified chemotherapy treatment and died 18 months after diagnosis from advanced-stage MM with pulmonary, pericardial, mediastinal, diaphragmatic, peritoneal and osseous metastases. The quantification of asbestos bodies in the lung parenchyma revealed the presence of 31,330 asbestos bodies per gram of dry lung tissue.

All three patients with variants were male and had no other malignancies in their clinical history.

\section{Discussion}

$B A P 1$ is a tumor-suppressor gene that encodes a $90-\mathrm{kDA}$ nuclear de-ubiquitinating enzyme. BAP1 protein acts through its de-ubiquitinase activity, regulating target genes in transcription, cell-cycle control, DNA damage repair and cellular differentiation [reviewed in (33)]. BAPl is located on chromosome $3 \mathrm{p} 21$, in a region that is often lost or deleted in various cancer types, including MM (8, 34-41).

Somatic BAP1 mutations and loss of BAP1 expression have been reported in presumably sporadic MM with frequencies ranging between 20 and $60 \%$ (8, 37, 40-48). These differences appeared related to either methodological or ethnical differences across various studies $(12,41)$. Previously, cyclin-dependent kinase inhibitor 2A (CDKN2A) and neurofibromin 2 (NF2) have been considered the most commonly mutated tumor-suppressor genes in MM [reviewed in (49)]. Now, however, BAPl has been identified as the gene with the highest rate of non-synonymous mutations in pleural MM $(37,41)$. These findings are supported by two nextgeneration sequencing studies of the MM genome, which revealed that various inactivating mutations occur randomly and are rarely shared among MM biopsies, with the exception of $B A P 1$, and to a lesser extent $N F 2, C D K N 2 A$, and possibly cullin 1 (CUL1) $(46,47,50)$. The observation that BAP1 mutation is such a frequent somatic event has also been confirmed in peritoneal MM $(49,51)$. Unlike MM occurring in germline $B A P 1$ mutations carriers, data concerning the clinical phenotype of $\mathrm{MM}$ with somatic $B A P 1$ mutation are controversial $(37,40,41,44,45,48,51,52)$.

Germline mutation of $B A P 1$ has been related to a recently identified autosomal dominant tumor predisposition syndrome (BAP1-TPDS) $(8-10,12,53)$ characterized by an increased risk for a specific skin lesion - atypical Spitz tumor - and various malignancies, mainly uveal melanoma, MM, cutaneous melanoma and renal cell carcinoma (54). Because of the limited number of families reported to date, the penetrance, natural history, and frequencies of $B A P 1$ - 
associated tumors are yet to be determined (54). The demonstration of a strong association with $B A P 1$ mutations, however, has most likely paved the way for comprehension of genetic predisposition to MM, which could account for the observation that only a small fraction of asbestosexposed individuals develop MM (5). A recent comprehensive review of published research into BAP1TPDS reported that $22 \%$ of patients with germline mutations were diagnosed with MM (55). MM occurring in individuals carrying germline $B A P 1$ mutations hasdistinct clinicopathological features, namely predilection for peritoneal involvement, earlier mean age of onset, less aggressive clinical course, and improved long-term survival $(12,54-57)$. Mutations in BAPl result in either complete absence of protein expression or cytoplasmic sequestration of BAP1, which can be detected by immunohistochemistry (41, 43-45, 48, 51).

In regard to the additional possible role of germline $B A P 1$ mutations in epidemiology of sporadic (non-familial) MM, Testa et al. suggested that these mutations are also frequent in sporadic MM because they found them in 2/26 (7.7\%) of patients with MM (8). Subsequent studies, however, have observed no BAPl mutations in truly unselected MM (58$61)$ so that, collectively, the prevalence of germline $B A P 1$ mutations in patients with sporadic MM can be considered lower than $1-2 \%$ (59). Thus, taken together, the screenings performed to date suggest a minor role of germline $B A P 1$ mutations in the pathogenesis of sporadic MM.

In our sample, we identified germline sequence variants of $B A P 1$ in $3 / 29$ asbestos-exposed patients and in $2 / 21$ sporadic MM cases. Web tools for prediction of alternative splicing and mutation pathogenicity, including in silico analysis, did not demonstrate any obvious functional significance of these variations. Thus, our results seem to be in agreement with most of the recent studies that support the notion that sporadic germline BAPl mutations are not relevant to genetic susceptibility to MM (58-61).

Nevertheless, it is recognized that tools available for predicting the pathogenicity of splicing alteration and amino acid change caused by point mutations have some limitations. Splicing regulatory elements act in concert, and their interactions and dependencies play an important role in splice site functionality, but the meaningful combination of cis-regulatory elements and splice site scores into a functional measure still remains to be achieved (62). Analogously, despite the availability of high-quality webbased tools, predicting the effect of missense mutations remains a challenging biophysics and bioinformatics problem. The main reason for this is that mutations can simultaneously affect several highly interrelated or correlated structural and physico-chemical characteristic of proteins, making it difficult to decouple them from one another (63, 64). Therefore, there may be aberrant splicing or missense

\section{G G G C C Y T G G A C}

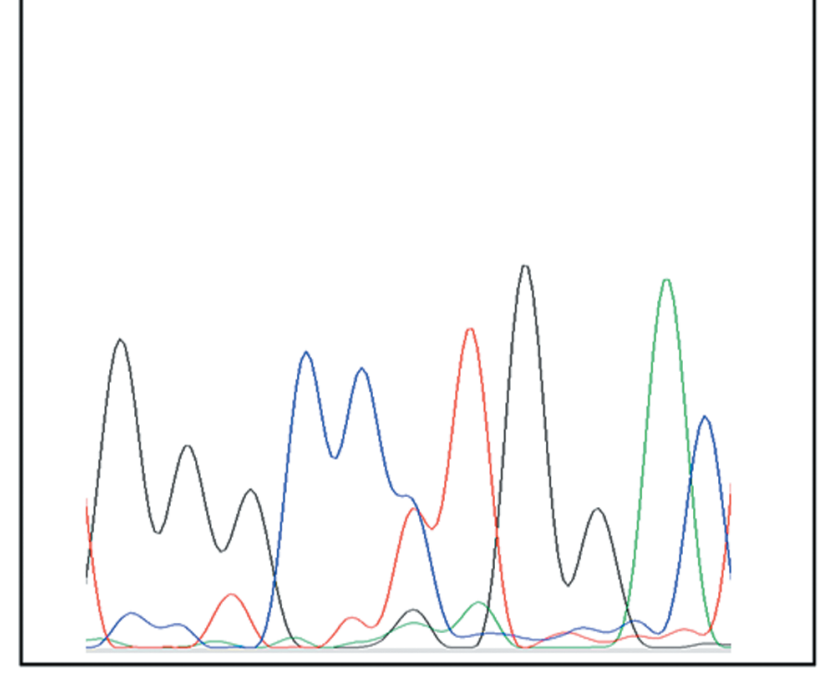

Figure 1. Partial electropherograms of the c.1729+8T $>C$ mutation of breast cancer 1-associated protein 1 (BAP1) gene in patient 4.

mutations that have an undetected impact on protein expression, conformation or function, so that the relevance of these changes for predisposition to tumor development remains to be explored $(59,62)$.

In the light of the above considerations, our findings present some peculiarities that are worth emphasizing and provide the opportunity to make some observations.

Patient 4 carried c. $1729+8 \mathrm{~T}>\mathrm{C}$ mutation and was affected by pulmonary fibrosis. He had no malignancies in his clinical history but, at autopsy, a clear cell renal cell carcinoma was evidenced as an incidental finding. It is clearly established that germline $B A P 1$ mutations predispose to renal cell carcinoma (65-67), and that renal cell carcinoma belongs to the phenotypic spectrum of BAP1-TPDS [reviewed in $(54,55)]$. BAP1 is most commonly mutated in sporadic clear cell renal cell carcinoma, with an incidence rate of $6-17 \%$. The inactivation of BAP1 has been associated with high tumor grade, rhabdoid/sarcomatoid transformation and poor prognosis (33).

Patient 9, who carried a non-synonymous mutation (c.T1028C; p.L343P) at exon 11, presents some intriguing peculiarities in his clinical history. MM developed in the form of multiple nodulations relatively circumscribed and distinct from one another, in a background of a widespread and marked pleural fibrosis, with features of desmoid-type fibromatosis. Diffuse pleural fibrosis is a benign pleural disease characterized by non-circumscribed fibrous thickening 
A

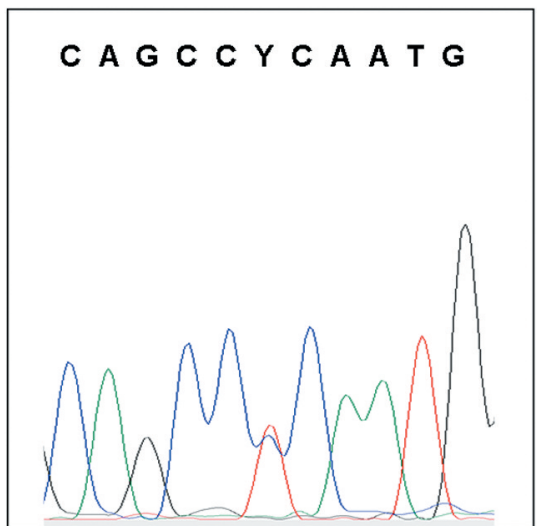

\section{BAP1:NM_004656.3; \\ C.1028T>C $;$ p.L343P}

B
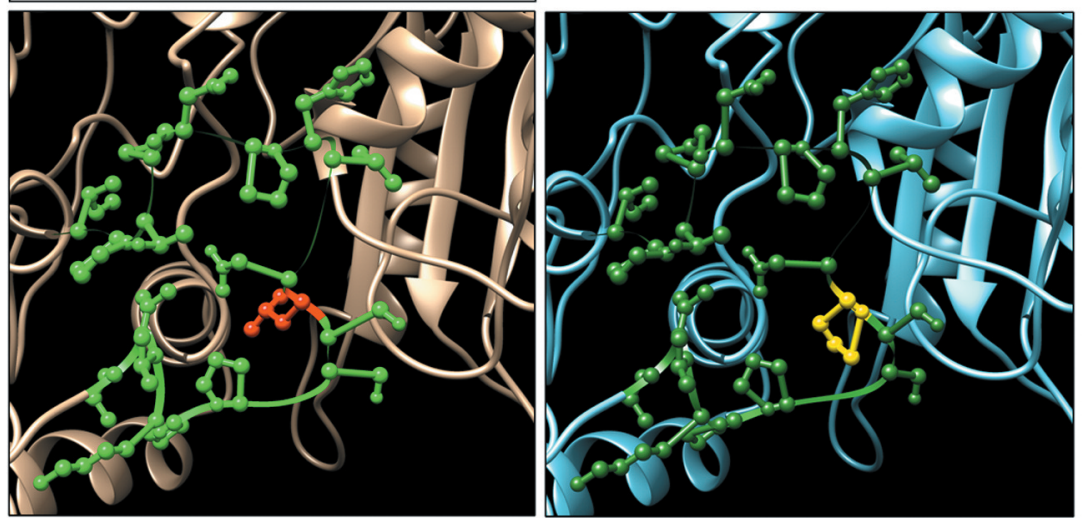

Figure 2. Partial electropherograms of the non-synonymous mutation of breast cancer 1-associated protein 1 (BAP1) gene in patient 9 (A). Wildtype and mutated amino acids are also evidenced on the structure reconstruction of the BAP1 protein. (B). Left, Wild-type leucine in red; right, mutated proline in yellow.

of variable cellularity involving mainly the visceral pleura, often described in association with moderate or heavy exposure to asbestos. The mechanism of development remains unclear, although it is thought to be a consequence of benign asbestos-induced pleuritis with effusion (3). On the other hand, primary desmoid-type fibromatosis arising primarily in the pleura is rare, and has never been reported in association with asbestos exposure to our knowledge. It is a locally aggressive but non-metastasizing myofibroblastic neoplasm that typically arises in deep soft tissues and often exhibits mutations in the gene encoding $\beta$-catenin $(C T N N B 1)(68,69)$. After diagnosis, the patient was subjected to pleurectomy and decortication, multiple pulmonary resections, chemotherapy and radiotherapy and survived for 41 months. Trimodality treatment may have contributed to prolonging survival because the stage of the disease allowed adequate radical surgical resection. In patients diagnosed at earlier stages and treated with extrapleural pneumonectomy followed by radiation and chemotherapy, survival rates of $38 \%$ after 2 years and $15 \%$ after 5 years have been reported (3). Nevertheless, considering the recent observation that $B A P 1$

\section{A T T C T R T T G T T}

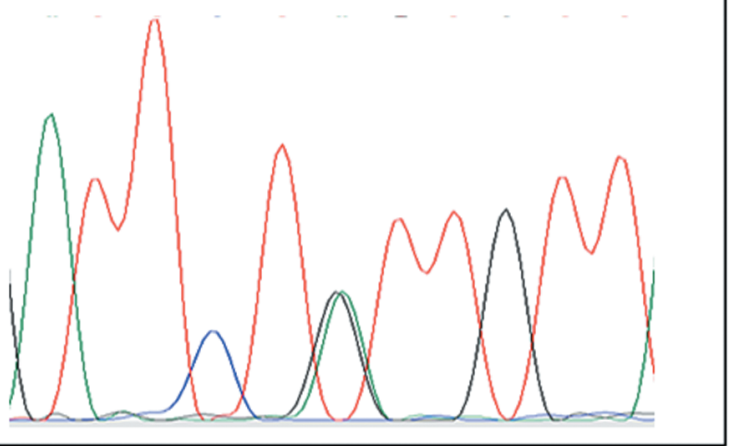

Figure 3. Partial electropherograms of the c.784-8G $>$ A mutation of breast cancer 1-associated protein 1 (BAP1) gene in patient 15 . 
germline mutation is associated with an improved long-term survival in MM $(12,54-57)$, it might also be speculated that there a relationship between such a peculiar clinical presentation and prolonged survival and the presence of missense variant in exon 11 of $B A P 1$.

Patient 15 carried c.784-8G $>$ A mutation and was affected by pleural epithelioid MM. Although he did not undergo surgery, survival from diagnosis was 18 months, in any case longer than the mean survival rates of patients with MM, which remains poor and typically around 12 months (1).

The role of asbestos exposure in germline BAPl mutation carriers is unclear (55). In the report by Testa et al., all family members affected by MM in both of the described families with germline mutations of BAPl lived in an asbestoscontaining home, and patients with sporadic MM carrying $B A P 1$ deletions had a history of exposure to asbestos (8). Studies in mice support a well-defined role of environmental carcinogens. When BAPl was deleted, mice developed myeloid transformation, but not MM, uveal or cutaneous melanoma (70), suggesting that germline BAPl mutations might increase the susceptibility to mineral fiber-induced and UV light-induced carcinogenesis (12). In mice with germline mutation of $B A P 1$, exposure to asbestos accelerates development of MM, also with involvement of dysregulation of the retinoblastoma pathway, thus confirming that high penetrance of MM requires such environmental exposure (71, 72). BAP1 acts as an important DNA damage signaling and repair enzyme (33), and may help prevent environmental carcinogenesis caused by asbestos or UV light. This would explain the very high incidence of MM, melanoma and basal cell carcinoma (rather than other not environmental related cancer types) among BAPl germline mutant carriers (73).

In order to investigate the role of germline $B A P 1$ mutation in asbestos-induced MM, Ohar et al. determined the prevalence of germline $B A P 1$ mutation in a population of asbestos-exposed MM cases. They found $B A P l$ alterations in $6 \%$ of patients, also confirming that $B A P 1$ mutation carriers develop $\mathrm{MM}$ at an earlier age that is more often peritoneal than pleural, and exhibit improved long-term survival compared to MM patients without BAPl mutations (61). The finding of an increase prevalence of inherited BAPl mutations in asbestos-exposed patients with MM versus asbestos-exposed controls appears to be consistent with the hypothesis that germline mutation in $B A P 1$ may contribute to susceptibility to $\mathrm{MM}$ in asbestos-exposed individuals through a mechanism that involves a geneenvironment interaction $(8,12)$. Napolitano et al. have suggested a novel, complex model of asbestos-induced MM pathogenesis that implicates tumor-suppressor effects of BAP1 mediated via the microenvironment, in which the asbestos-induced chronic inflammatory response can have preferentially anti-tumoral or pro-tumoral roles, depending on the cellular and soluble mediators involved (74). Thus,
BAP1 mutation carriers may be highly susceptible to MM even at modest background levels of asbestos exposure that would be considerably less tumorigenic for the general population $(56,57,71,74)$. This could explain observations of minimal or no evidence of exposure to asbestos among patients carrying $B A P 1$ germline mutations who developed MM (8, 11, 58). An additional role of gene-asbestos interaction on MM susceptibility also emerges from a study examining interactions between asbestos exposure and a set of candidate single nucleotide polymorphisms deriving from a genome-wide association study on pleural MM $(75,76)$. Alternatively, these MMs might be totally unrelated to exposure to asbestos $(8,56,57)$. Indeed, no statistically significant effect of asbestos exposure on BAP1 protein expression has been found (44).

In our series, both mesothelioma cases (patients 9 and 15) harboring $B A P 1$ variants had a story of occupational exposure to asbestos. For patient 9, despite the long lasting and high level of asbestos exposure (he was been employed as a fireman and lubricator in the engine room of a ship and then, for a long time, in the technical office of shipyards in Trieste and Monfalcone), there were only 229 asbestos bodies per gram of dry lung tissue. According to guidelines, over 1000 asbestos bodies per gram of dry tissue are required in order to identify persons with a high probability of exposure to asbestos dust (3), and a relationship between asbestos burden and survival in pleural MM has also been demonstrated (77). Nevertheless, the mechanism responsible for this dose-response association with survival is unclear and possibly attributable once again to genetic susceptibility (77), which might at the same time be able to influence the process of formation of asbestos bodies as an epiphenomenon. Patient 15 had been a welder for 43 years and the asbestos content of his lungs (31,330 asbestos bodies per gram of dry lung tissue) was consistent with a high level of exposure.

In conclusion, we analyzed the prevalence of germline $B A P 1$ mutations in a group of asbestos-exposed patients who had lived and worked in Trieste, a ship-building town in Northeast Italy with a very high incidence of mesothelioma. As far as we are aware, this is the first published study dealing with the topic in this high-risk area. In 3/29 patients and in $2 / 21 \mathrm{MM}$ cases, we found non obviously pathogenic germline sequence variants of BAPl. Nevertheless, limitations of web tools for prediction impose reservations in the interpretation of some puzzling features of our findings.

\section{References}

1 Marshall AD, Bayes HK, Bardgett J, Wedderburn S, Kerr KM and Currie GP: Survival from malignant mesothelioma: Where are we now? J R Coll Physicians Edinb 45: 123-126, 2015. 
2 IARC Working Group on the Evaluation of Carcinogenic Risks to Humans (Lyon, France, 2009): Asbestos. In: IARC Monographs on the Evaluation of Carcinogenic Risks to Humans. Arsenic, Metals, Fibres, and Dusts. a Review of Human Carcinogens. Vol. 100C. Lyon, France, pp. 219-309, 2012.

3 Wolff H, Vehmas T, Oksa P, Rantanen J and Vainio H: Asbestos, asbestosis, and cancer, the Helsinki criteria for diagnosis and attribution 2014: recommendations. Scand J Work Environ Health 41: 5-15, 2015.

4 Novello S, Pinto C, Torri V, Porcu L, Di Maio M, Tiseo M, Ceresoli G, Magnani C, Silvestri S, Veltri A, Papotti M, Rossi G, Ricardi U, Trodella R, Rea F, Facciolo F, Granieri A, Zagonel V and Scagliotti G: The Third Italian Consensus Conference for Malignant Pleural Mesothelioma: State of the art and recommendations. Crit Rev Oncol Hematol 104: 9-20, 2016.

5 Hodgson JT and Darnton A: The quantitative risks of mesothelioma and lung cancer in relation to asbestos exposure. Ann Occup Hyg 44: 565-601, 2000.

6 Carbone M, Emri S, Dogan AU, Steele I, Tuncer M, Pass HI and Baris YI: A mesothelioma epidemic in Cappadocia: scientific developments and unexpected social outcomes. Nat Rev Cancer 7: 147-154, 2007.

7 Carbone M, Baris YI, Bertino P, Brass B, Comertpay S, Dogan AU, Gaudino G, Jube S, Kanodia S, Partridge CR, Pass HI, Rivera ZS, Steele I, Tuncer M, Way S, Yang H and Miller A: Erionite exposure in North Dakota and Turkish villages with mesothelioma. Proc Natl Acad Sci USA 108: 13618-13623, 2011.

8 Testa JR, Cheung M, Pei J, Below JE, Tan Y, Sementino E, Cox NJ, Dogan AU, Pass HI, Trusa S, Hesdorffer M, Nasu M, Powers A, Rivera Z, Comertpay S, Tanji M, Gaudino G, Yang $\mathrm{H}$ and Carbone M: Germline BAP1 mutations predispose to malignant mesothelioma. Nat Genet 43: 1022-1025, 2011.

9 Carbone M, Ferris LK, Baumann F, Napolitano A, Lum CA, Flores EG, Gaudino G, Powers A, Bryant-Greenwood P, Krausz T, Hyjek E, Tate R, Friedberg J, Weigel T, Pass HI and Yang H: $B A P 1$ cancer syndrome: malignant mesothelioma, uveal and cutaneous melanoma, and MBAITs. J Transl Med 10: 179, 2012.

10 Wiesner T, Obenauf AC, Murali R, Fried I, Griewank KG, Ulz $\mathrm{P}$, Windpassinger C, Wackernagel W, Loy S, Wolf I, Viale A, Lash AE, Pirun M, Socci ND, Rütten A, Palmedo G, Abramson D, Offit K, Ott A, Becker JC, Cerroni L, Kutzner H, Bastian BC and Speicher MR: Germline mutations in BAP1 predispose to melanocytic tumors. Nat Genet 43: 1018-1021, 2011.

11 Wiesner T, Fried I, Ulz P, Stacher E, Popper H, Murali R, Kutzner H, Lax S, Smolle-Jüttner F, Geigl JB and Speicher MR: Toward an improved definition of the tumor spectrum associated with BAP1 germline mutation. J Clin Oncol 30: e337-340, 2012.

12 Carbone M, Yang H, Pass HI, Krausz T, Testa JR and Gaudino G: BAP1 and cancer. Nat Rev Cancer 13: 153-159, 2013.

13 Birri S, Bidoli E, Zucchetto A, Dal Maso L, Zanier L and Serraino D: Sintesi di Area Vasta. In: I tumori in Friuli Venezia Giulia. Dati di incidenza, sopravvivenza e prevalenza: aggiornamento al 2007. Udine, Italy, p. 28, 2011.

14 Serraino D, Bidoli E, De Paoli A, de Dottori M, Zucchetto A and Zanier L: Appendici. In: I tumori in Friuli Venezia Giulia. Dati di incidenza, sopravivenza e prevalenza: 1995-2005. Udine, Italy, pp. 65 and 69, 2009.

15 AIOM-AIRTUM Working Group: Confronti geografici nazionali. In: I numeri del cancro in Italia 2016 (Il Pensiero Scientifico ed.). Roma, Italy, p. 62, 2016.
16 WHO classification of tumours of the pleura. In: WHO Classification of Tumours. Pathology and Genetics. Tumours of the Lung, Pleura, Thymus and Heart. Travis WD, Brambilla E, Burke AP, Marx A and Nicholson AG (eds.). Lyon, France, IARC Press, p. 154, 2015.

17 Roggli VL, Gibbs AR, Attanoos R, Churg A, Popper H, Cagle P, Corrin B, Franks TJ, Galateau-Salle F, Galvin J, Hasleton PS, Henderson DW and Honma K. Pathology of asbestosis - An update of the diagnostic criteria: Report of the Asbestosis Committee of the College of American Pathologists and Pulmonary Pathology Society. Arch Pathol Lab Med 134: 462480, 2010.

18 Smith MJ and Naylor B: A method for extracting ferruginous bodies from sputum and pulmonary tissue. Am J Clin Pathol 58: 250-254, 1972

19 Bortot B, Athanasakis E, Brun F, Rizzotti D, Mestroni L, Sinagra G and Severini GM: High-throughput genotyping robot-assisted method for mutation detection in patients with hypertrophic cardiomyopathy. Diagn Mol Pathol 20: 175-179, 2011.

20 Koressaar T and Remm M: Enhancements and modifications of primer design program Primer3. Bioinformatics 23: 1289-1291, 2007.

21 Untergasser A, Cutcutache I, Koressaar T, Ye J, Faircloth BC, Remm $M$ and Rozen SG: Primer3-new capabilities and interfaces. Nucleic Acids Res 40: e115, 2012.

22 Ye J, Coulouris G, Zaretskaya I, Cutcutache I, Rozen S and Madden TL: Primer-BLAST: a tool to design target-specific primers for polymerase chain reaction. BMC Bioinformatics 13: 134, 2012.

23 Wang K, Li M and Hakonarson H: ANNOVAR: functional annotation of genetic variants from high-throughput sequencing data. Nucleic Acids Res 38: e164, 2010.

24 Desmet FO, Hamroun D, Lalande M, Collod-Béroud G, Claustres $\mathrm{M}$ and Béroud C: Human Splicing Finder: an online bioinformatics tool to predict splicing signals. Nucleic Acids Res 37: e67, 2009.

25 Reese MG, Eeckman FH, Kulp D and Haussler D: Improved splice site detection in Genie. J Comput Biol 4: 311-323, 1997.

26 Hebsgaard SM, Korning PG, Tolstrup N, Engelbrecht J, Rouzé $\mathrm{P}$ and Brunak S: Splice site prediction in Arabidopsis thaliana pre-mRNA by combining local and global sequence information. Nucleic Acids Res 24: 3439-3452, 1996.

27 Xiong HY, Alipanahi B, Lee LJ, Bretschneider H, Merico D, Yuen RK, Hua Y, Gueroussov S, Najafabadi HS, Hughes TR, Morris Q, Barash Y, Krainer AR, Jojic N, Scherer SW, Blencowe BJ and Frey BJ: RNA splicing. The human splicing code reveals new insights into the genetic determinants of disease. Science 347: 1254806, 2015.

28 Kelley LA, Mezulis S, Yates CM, Wass MN and Sternberg MJ: The Phyre2 web portal for protein modeling, prediction and analysis. Nat Protoc 10: 845-858, 2015.

29 Pettersen EF, Goddard TD, Huang CC, Couch GS, Greenblatt DM, Meng EC and Ferrin TE: UCSF Chimera-a visualization system for exploratory research and analysis. J Comput Chem 25: 1605-1612, 2004.

30 Schouten JP, McElgunn CJ, Waaijer R, Zwijnenburg D, Diepvens F and Pals G: Relative quantification of 40 nucleic acid sequences by multiplex ligation-dependent probe amplification. Nucleic Acids Res 30: e57, 2002.

31 The 1000 Genomes Project Consortium: A map of human genome variation from population-scale sequencing. Nature 467: 1061-1073, 2010. 
32 Exome Variant Service, NHLBI GO Exome Sequencing Project (ESP), Seattle, WA (URL: http://evs.gs.washington.edu/EVS/) [accessed October 2016].

33 Wang A, Papneja A, Hyrcza M, Al-Habeeb A and Ghazarian D: BAP1: gene of the month. J Clin Pathol 69: 750-753, 2016.

34 Taguchi T, Jhanwar SC, Siegfried JM, Keller SM and Testa JR: Recurrent deletions of specific chromosomal sites in 1p, 3p, 6q, and $9 \mathrm{p}$ in human malignant mesothelioma. Cancer Res 53: 4349$4355,1993$.

35 Lu YY, Jhanwar SC, Cheng JQ and Testa JR: Deletion mapping of the short arm of chromosome 3 in human malignant mesothelioma. Genes Chromosomes Cancer 9: 76-80, 1994.

36 Zeiger MA, Gnarra JR, Zbar B, Linehan WM and Pass HI: Loss of heterozygosity on the short arm of chromosome 3 in mesothelioma cell lines and solid tumors. Genes Chromosomes Cancer 11: 15-20, 1994.

37 Bott M, Brevet M, Taylor BS, Shimizu S, Ito T, Wang L, Creaney J, Lake RA, Zakowski MF, Reva B, Sander C, Delsite R, Powell S, Zhou Q, Shen R, Olshen A, Rusch V and Ladanyi $\mathrm{M}$ : The nuclear deubiquitinase BAP1 is commonly inactivated by somatic mutations and $3 \mathrm{p} 21.1$ losses in malignant pleural mesothelioma. Nat Genet 43: 668-672, 2011.

38 Yoshikawa Y, Sato A, Tsujimura T, Morinaga T, Fukuoka K, Yamada S, Murakami A, Kondo N, Matsumoto S, Okumura Y, Tanaka F, Hasegawa S, Hashimoto-Tamaoki T and Nakano T: Frequent deletion of $3 \mathrm{p} 21.1$ region carrying semaphorin $3 \mathrm{G}$ and aberrant expression of the genes participating in semaphorin signaling in the epithelioid type of malignant mesothelioma cells. Int J Oncol 39: 1365-1374, 2011.

39 Murali R, Wiesner T and Scolyer RA: Tumours associated with BAP1 mutations. Pathology 45: 116-126, 2013.

40 Zauderer MG, Bott M, McMillan R, Sima CS, Rusch V, Krug LM and Ladanyi M: Clinical characteristics of patients with malignant pleural mesothelioma harboring somatic BAP1 mutations. J Thorac Oncol 8: 1430-1433, 2013.

41 Nasu M, Emi M, Pastorino S, Tanji M, Powers A, Luk H, Baumann F, Zhang YA, Gazdar A, Kanodia S, Tiirikainen M, Flores E, Gaudino G, Becich MJ, Pass HI, Yang H and Carbone M: High incidence of somatic BAP1 alterations in sporadic malignant mesothelioma. J Thorac Oncol 10: 565-576, 2015.

42 Forbes SA, Bindal N, Bamford S, Cole C, Kok CY, Beare D, Jia M, Shepherd R, Leung K, Menzies A, Teague JW, Campbell PJ, Stratton MR and Futreal PA: COSMIC: mining complete cancer genomes in the Catalogue of Somatic Mutations in Cancer. Nucleic Acids Res 39: D945-950, 2011.

43 Yoshikawa Y, Sato A, Tsujimura T, Emi M, Morinaga T, Fukuoka K, Yamada S, Murakami A, Kondo N, Matsumoto S, Okumura Y, Tanaka F, Hasegawa S, Nakano T and Hashimoto-Tamaoki T: Frequent inactivation of the BAPl gene in epithelioid-type malignant mesothelioma. Cancer Sci 103: 868-874, 2012.

44 Arzt L, Quehenberger F, Halbwedl I, Mairinger T and Popper $\mathrm{HH}$ : BAP1 protein is a progression factor in malignant pleural mesothelioma. Pathol Oncol Res 20: 145-151, 2014.

45 Farzin M: Loss of expression of BAP1 predicts longer survival in MM. Pathology 47: 302-307, 2015.

46 Guo G, Chmielecki J, Goparaju C, Heguy A, Dolgalev I, Carbone M, Seepo S, Meyerson M and Pass HI: Whole-exome sequencing reveals frequent genetic alterations in $B A P 1, N F 2$, $C D K N 2 A$, and $C U L 1$ in malignant pleural mesothelioma. Cancer Res 75: 264-269, 2015.
47 Lo Iacono M, Monica V, Righi L, Grosso F, Libener R, Vatrano S, Bironzo P, Novello S, Musmeci L, Volante M, Papotti M and Scagliotti GV: Targeted next-generation sequencing of cancer genes in advanced stage malignant pleural mesothelioma: a retrospective study. J Thorac Oncol 10: 492-499, 2015.

48 McGregor SM, Dunning R, Hyjek E, Vigneswaran W, Husain AN and Krausz T: BAP1 facilitates diagnostic obiectivity, classification, and prognostication in malignant pleural mesothelioma. Hum Pathol 46: 1670-1678, 2015.

49 Alakus H, Yost SE, Woo B, French R, Lin GY, Jepsen K, Frazer $\mathrm{KA}$, Lowy AM and Harismendy O: BAP1 mutation is a frequent somatic event in peritoneal malignant mesothelioma. J Transl Med 13: 122, 2015.

50 Hylebos M, Van Camp G, van Meerbeeck JP and Op de Beeck $\mathrm{K}$ : The genetic landscape of malignant pleural mesothelioma: results from massively parallel sequencing. J Thorac Oncol 11 : 1615-1626, 2016.

51 Singhi AD, Krasinskas AM, Choudry HA, Bartlett DL, Pingpank JF, Zeh HJ, Luvison A, Fuhrer K, Bahary N, Seethala RR and Dacic S: The prognostic significance of $B A P 1, N F 2$, and $C D K N 2 A$ in malignant peritoneal mesothelioma. Mod Pathol 29: 14-24, 2016.

52 de Reyniès A, Jaurand MC, Renier A, Couchy G, Hysi I, Elarouci N, Galateau-Sallé F, Copin MC, Hofman P, Cazes A, Andujar P, Imbeaud S, Petel F, Pairon JC, Le Pimpec-Berthes F, Zucman-Rossi $\mathrm{J}$ and Jean D: Molecular classification of malignant pleural mesothelioma: identification of a poor prognosis subgroup linked to the epithelial-to-mesenchymal transition. Clin Cancer Res 20: 1323-1334, 2014.

53 Abdel-Rahman MH, Pilarski R, Cebulla CM, Massengill JB, Christopher BN, Boru G, Hovland P and Davidorf FH: Germline $B A P 1$ mutation predisposes to uveal melanoma, lung adenocarcinoma, meningioma, and other cancers. J Med Genet 48: 856-859, 2011

54 Pilarski R, Rai K, Cebulla C and Abdel-Rahman M: BAP1 Tumor Predisposition Syndrome. In: GeneReviews ${ }^{\circledR}$. Pagon RA, Adam MP, Ardinger HH, Wallace SE, Amemiya A, Bean LJH, Bird TD, Ledbetter N, Mefford HC, Smith RJH and Stephens K (eds). Seattle (WA), University of Washington, Seattle, 19932017, 2016

55 Rai K, Pilarski R, Cebulla CM and Abdel-Rahman MH: Comprehensive review of BAP1 tumor predisposition syndrome with report of two new cases. Clin Genet 89: 285-294, 2016.

56 Baumann F: MM patients with germline BAP1 mutation have 7fold improved long-term survival. Carcinogenesis 36: 78-81, 2015.

57 Carbone M, Flores EG, Emi M, Johnson TA, Tsunoda T, Behner D, Hoffman H, Hesdorffer M, Nasu M, Napolitano A, Powers A, Minaai M, Baumann F, Bryant-Greenwood P, Lauk O, Kirschner MB, Weder W, Opitz I, Pass HI, Gaudino G, Pastorino $\mathrm{S}$ and Yang $\mathrm{H}$ : Combined genetic and genealogic studies uncover a large $B A P l$ cancer syndrome kindred tracing back nine generations to a common ancestor from the 1700s. PLoS Genet 11: e1005633, 2015.

58 Betti M, Casalone E, Ferrante D, Romanelli A, Grosso F, Guarrera S, Righi L, Vatrano S, Pelosi G, Libener R, Mirabelli D, Boldorini R, Casadio C, Papotti M, Matullo G, Magnani C and Dianzani I: Inference on germline $B A P 1$ mutations and asbestos exposure from the analysis of familial and sporadic mesothelioma in a high-risk area. Genes Chromosomes Cancer 54: 51-62, 2015. 
59 Rusch A, Ziltener G, Nackaerts K, Weder W, Stahel RA and Felley-Bosco E: Prevalence of BRCA-1 associated protein 1 germline mutation in sporadic malignant pleural mesothelioma cases. Lung Cancer 87: 77-79, 2015.

60 Sneddon S, Leon JS, Dick IM, Cadby G, Olsen N, Brims F, Allcock RJ, Moses EK, Melton PE, de Klerk N, Musk AW, Robinson BW and Creaney J: Absence of germline mutations in $B A P 1$ in sporadic cases of malignant mesothelioma. Gene 563: 103-105, 2015.

61 Ohar JA, Cheung M, Talarchek J, Howard SE, Howard TD, Hesdorffer M, Peng H, Rauscher FJ and Testa JR: Germline BAP1 mutational landscape of asbestos-exposed malignant mesothelioma patients with family history of cancer. Cancer Res 76: 206-215, 2016.

62 Hartmann L, Theiss S, Niederacher D and Schaal H: Diagnostics of pathogenic splicing mutations: Does bioinformatics cover all bases? Front Biosci 13: 3252-3272, 2008.

63 Kucukkal TG, Petukh M, Li L and Alexov E: Structural and physico-chemical effects of disease and non-disease nsSNPs on proteins. Curr Opin Struct Biol 32: 18-24, 2015.

64 Stefl S, Nishi H, Petukh M, Panchenko AR and Alexov E: Molecular mechanisms of disease-causing missense mutations. J Mol Biol 425: 3919-3936, 2013.

65 Peña-Llopis S, Vega-Rubín-de-Celis S, Liao A, Leng N, PavíaJiménez A, Wang S, Yamasaki T, Zhrebker L, Sivanand S, Spence P, Kinch L, Hambuch T, Jain S, Lotan Y, Margulis V, Sagalowsky AI, Summerour PB, Kabbani W, Wong SW, Grishin N, Laurent M, Xie XJ, Haudenschild CD, Ross MT, Bentley DR, Kapur $\mathrm{P}$ and Brugarolas J: BAP1 loss defines a new class of renal cell carcinoma. Nat Genet 44: 751-759, 2012.

66 Popova T: Germline BAP1 mutations predispose to renal cell carcinomas. Am J Hum Gen 92: 974-980, 2013.

67 Farley MN, Schmidt LS, Mester JL, Peña-Llopis S, PaviaJimenez A, Christie A, Vocke CD, Ricketts CJ, Peterson J, Middelton L, Kinch L, Grishin N, Merino MJ, Metwalli AR, Xing C, Xie XJ, Dahia PL, Eng C, Linehan WM and Brugarolas $\mathrm{J}$ : A novel germline mutation in $B A P 1$ predisposes to familial clear-cell renal cell carcinoma. Mol Cancer Res 11: 1061-1071, 2013.

68 Fletcher CDM and Cagle P: Tumours of the pleura. Mesenchymal tumours. Desmoid-type fibromatosis. In: WHO Classification of Tumours. Pathology and Genetics. Tumours of the Lung, Pleura, Thymus and Heart. Travis WD, Brambilla E, Burke AP, Marx A and Nicholson AG (eds.). Lyon, France, IARC Press, p. 179-180, 2015.

69 Goldblum JR and Fletcher JA: Fibroblastic/Myofibroblastic tumours. Desmoid-type fibromatosis. In: WHO Classification of Tumours. Pathology and Genetics. Tumours of Soft Tissue and Bone. Fletcher CDM, Bridge JA, Hogendoorn PCW and Mertens F (eds.). Lyon, France, IARC Press, pp. 72-73, 2013.
70 Dey A, Seshasayee D, Noubade R, French DM, Liu J, Chaurushiya MS, Kirkpatrick DS, Pham VC, Lill JR, Bakalarski CE, Wu J, Phu L, Katavolos P, LaFave LM, Abdel-Wahab O, Modrusan Z, Seshagiri S, Dong K, Lin Z, Balazs M, Suriben R, Newton K, Hymowitz S, Garcia-Manero G, Martin F, Levine RL and Dixit VM: Loss of the tumor-suppressor BAP1 causes myeloid transformation. Science 337: 1541-1546, 2012.

71 Xu J, Kadariya Y, Cheung M, Pei J, Talarchek J, Sementino E, Tan Y, Menges CW, Cai KQ, Litwin S, Peng H, Karar J, Rauscher FJ and Testa JR: Germline mutation of Bapl accelerates development of asbestos-induced malignant mesothelioma. Cancer Res 74: 4388-4397, 2014.

72 Kadariya Y, Cheung M, Xu J, Pei J, Sementino E, Menges CW, Cai KQ, Rauscher FJ, Klein-Szanto AJ and Testa JR: Bapl is a bona-fide tumor suppressor: genetic evidence from mouse models carrying heterozygous germline Bap1 mutations. Cancer Res 76: 2836-2844, 2016.

73 Carbone $M$ and Yang $\mathrm{H}$ : Molecular pathways: targeting mechanisms of asbestos and erionite carcinogenesis in mesothelioma. Clin Cancer Res 18: 598-604, 2012.

74 Napolitano A, Pellegrini L, Dey A, Larson D, Tanji M, Flores EG, Kendrick B, Lapid D, Powers A, Kanodia S, Pastorino S, Pass HI, Dixit V, Yang H and Carbone M: Minimal asbestos exposure in germline Bapl heterozygous mice is associated with deregulated inflammatory response and increased risk of mesothelioma. Oncogene 35: 1996-2002, 2016.

75 Tunesi S, Ferrante D, Mirabelli D, Andorno S, Betti M, Fiorito G, Guarrera S, Casalone E, Neri M, Ugolini D, Bonassi S, Matullo G, Dianzani I and Magnani C: Gene-asbestos interaction in malignant pleural mesothelioma susceptibility. Carcinogenesis 36: 1129-1135, 2015.

76 Matullo G, Guarrera S, Betti M, Fiorito G, Ferrante D, Voglino F, Cadby G, Di Gaetano C, Rosa F, Russo A, Hirvonen A, Casalone E, Tunesi S, Padoan M, Giordano M, Aspesi A, Casadio C, Ardissone F, Ruffini E, Betta PG, Libener R, Guaschino R, Piccolini E, Neri M, Musk AWB, de Klerk NH, Hui J, Beilby J, James AL, Creaney J, Robinson BW, Mukherjee S, Palmer LJ, Mirabelli D, Ugolini D, Bonassi S, Magnani C and Dianzani I: Genetic variants associated with increased risk of malignant pleural mesothelioma: a genome-wide association study. PLoS One 8: e61253, 2013.

77 Christensen BC, Godleski JJ, Roelofs CR, Longacker JL, Bueno R, Sugarbaker DJ, Marsit CJ, Nelson HH and Kelsey KT: Asbestos burden predicts survival in pleural mesothelioma. Environ Health Perspect 116: 723-726, 2008.

Received April 18, 2017

Revised May 12, 2017

Accepted May 16, 2017 